\title{
53- Çin çeviri tarihinde Batı etkisi ve modernleşme girişimleri: “Tongwen Guan (同文館)” çeviri okulu örneği
}

Çile MADEN KALKAN ${ }^{1}$

Aylin YILMAZ ŞAŞMAZ ${ }^{2}$

APA: Maden Kalkan, Ç.; Yılmaz Şaşmaz, A. (2021). Çin çeviri tarihinde Batı etkisi ve modernleşme girişimleri: “Tongwen Guan (同文館)” çeviri okulu örneği. RumeliDE Dil ve Edebiyat Araştırmalart Dergisi, (25), 892-909. DOI: 10.29000/rumelide.1032537.

\section{$\ddot{O} \mathbf{z}$}

Çeviri, en basit anlamıyla bir dilden başka bir dile dolayısıyla da bir kültürden başka bir kültüre yapılan sözlü ve yazılı aktarımların tümüdür. Çin'de bilinen en eski kayıtlı çeviri faaliyetleri, Zhou Hanedanı'na (周朝/MÖ 1122-221) kadar uzanmaktadır. Bu ülkenin çeviri tarihini üç aktarım sürecine ayıracak olursak, ilk aktarım Budizm’in Çin’e gelişiyle birlikte dini metin çevirileri ile başlamıştır. İkinci aktarım ise 16. ve 17 yüzyıllarda Cizvit misyonerlerin Katolikliği yayma çabalarıyla ve ağırlıklı olarak dini metinlerin yanı sıra bilimsel metinlerin de çevrilmesi ile devam etmiştir. Üçüncü aktarım ise 19. ve 20. yüzyıllarda ağırlıklı olarak Batı biliminin çevrilmesi ile gerçekleşmiştir. Böylece ülkede batılılaşma ile eş anlamlı hale gelen bir modernleşme sürecinin başladığı yaygın olarak kabul edilir. Afyon Savaşları'nda aldığı yenilgilerin de etkisiyle Çin bu süreçte büyük bir uyanış geçirmiş, gelenekselci özünü kaybetmeden Batıdan sadece bilimi geliştirme anlamında faydalanabilmek için çeviriye daha fazla önem vermiştir. Bu doğrultuda hükümet, kendi çevirmenini yetiştirmek ve iki dil bilen kaliteli memur ihtiyacını karşılamak için 1862 yılında “Tongwen Guan (同文館)” çeviri okulunu kurmuştur. Çalışmanın amacı; çeviri deyince akla ilk gelen Batı dünyasının yanı sıra Doğu'yu da Çin üzerinden inceleyip ele alarak, çeviribilim alanına Doğu'dan bir örnekle katkı sağlamaktır. Çalışmada veri toplamak amacıyla China Academic Journals (CNKI) veri tabanı ve açık kaynaklardan elde edilen bilgiler ve bu alanda yazılmış kitaplar kullanılarak uzun Çin tarihi içerisinde çevirinin rolü incelenmiştir. Bu doğrultuda Çin'de çevirinin, ülkenin geleneksel dünya algısı ve bazı hükümet politikaları çerçevesinde olumlu anlamda şekillendiği gözlemlenmiştir. Günümüzdeki modern Çin, ülkenin Batı liderliğindeki bir dünya sisteminde kendi yolunu bulup, fırsatlarını keşfetmesiyle mümkün olmuştur.

Anahtar kelimeler: Çin, çeviribilim, çeviri tarihi, Tongwen Guan (同文館), çeviri okulu

\section{Western influence and modernization attempts in Chinese translation history: the example of “Tongwen Guan (同文館)” translation school}

\begin{abstract}
Translation, in its simplest sense, is all of the verbal and written transfers from one language to another. The earliest known recorded translation activities in China date back to the Zhou Dynasty ( 周朝/1122-221 $\mathrm{BC}$ ). If we divide the translation history of this country into three transmission

Arş. Gör., Ankara Hacı Bayram Veli Üniversitesi, Edebiyat Fakültesi, Sosyal Bilimler Enstitüsü, Mütercim Tercümanlık Bölümü, Çince Mütercim Tercümanlık ABD (Ankara, Türkiye), cile.maden@hbv.edu.tr, ORCID ID: oooo-00o3-47367101 [Araştırma makalesi, Makale kayıt tarihi: 05.10.2021-kabul tarihi: 20.11.2021; DOI: 10.29000/rumelide.1032537] Arş. Gör., Ankara Hacı Bayram Veli Universitesi, Edebiyat Fakültesi, Sosyal Bilimler Enstitüsü, Mütercim Tercümanlı Bölümü, Çince Mütercim Tercümanlık ABD (Ankara, Türkiye), aylin.yilmaz@hbv.edu.tr, ORCID ID: 00oo-0001-78634140
\end{abstract}


processes, the first transmission started with the arrival of Buddhism in China. The second transmission continued with the efforts of Jesuit missionaries to spread Catholicism in the 16th and 17th centuries. The third transfer took place mainly by the translation of Western science in the 19th and 2oth centuries. Thus, it is widely accepted that a modernization process has begun in the country, which has become synonymous with westernization. With the effect of the defeats in the Opium Wars, China had a great awakening in this process and gave more importance to translation in order to benefit from the West only in terms of developing science without losing its traditionalist essence. In this direction, the government established the "Tongwen Guan (同文館)" translation school in 1862 to train its own translators and to meet the need for qualified bilingual officials. The aim of the study is to contribute to the field of translation studies by examining and addressing the East through China. In order to collect data in the study; CNKI database, open sources and books written in this field were used. In this respect, it has been observed that translation in China is shaped positively within the framework of the country's traditional world perception and some government policies.

Keywords: China, translation studies, translation history, Tongwen Guan (同文館), translation school

\section{Giriş}

Çin'de bilinen en eski kayıtlı çeviri faaliyetleri, Zhou Hanedanı'na (周朝/MÖ 1122-221) kadar uzanmaktadır. Zhou Li (周禮) ve Li Ji (禮記) olarak bilinen Konfüçyüs klasiklerinden ikisinde, çevirmenler adına yalnızca resmi unvanları ve pozisyonları kaydetmekle kalınmamış, aynı zamanda çevirinin kökeni de şu ifadelerle açıklanmıştır:

"Ülkenin farklı bölgelerinde yaşayan insanlar birbirlerinin dillerini anlayamadılar. Onların beğenileri, ihtiyaçları ve arzuları farklıydı. Görevleri bu insanların fikirlerini anlamak, beğenilerini ve ihtiyaçlarını iletmek olan görevliler vardı. Bu memurlar doğuda “ji (寄)”, güneyde “xiang (象)”, batıda “didi (狄鞮)” ve kuzeyde “yi (譯)” görevlerinde bulundular (Ruan, 1980: 899).”3

“Xiang Xu’nun (象胥) görevleri, Man (蠻), Yi (夷), Min (閩), He (貉), Rong (戎) ve Di (狄) kavimlerinden elçileri karşılamak, onlara imparatorun sözlerini iletmek ve açıklamaktı, böylece bu devletlerle uyumlu bir ilişki sürdürüldü. Bu devletlerin elçileri veya başkanları imparator ile görüşmeye geldiklerinde, Xiangxu protokole katılır, diplomatik dili kullanarak, onlar adına tercümanlık yapardı (Ruan, 1980: 1338).”4

1911 yllındaki 4 Mayıs Hareketi’nden (五四運動/1919) önce Çin çeviri tarihinde önemli üç çeviri dönemi olduğu kabul edilmektedir. Bu dönemlerden birincisi Budizm’in Çin’e girişiyle başlamaktadır. Bu süreçte çeviri vasıtasıyla Budist fikirler yavaş yavaş Çinliler arasında kabul görmeye başlamıştır. Yani, ilk çeviri patlaması Çin’in parçalanma döneminde5 Budist rahiplerin Budizm’in devasa klasiklerini Çinceye çevirmeleri ile başlamıştır. Budist çeviri faaliyetleri Tang (唐朝/618-907) ve Song (宋朝/ 9601279) Hanedanlarına kadar sürmüştür. Dönemin çevirileri ağırlıklı olarak dini metinlerden oluştuğundan, çevirmenler için: "1. Budist öğretilere sadık olmak, 2. Hedef kitle inananlarına fayda sağlamak, 3. Meşhur olmak için tercüme yapmak yerine Budist öğretinin tercümesine odaklanmak (Ma, 1984: 45)" gibi belli kurallar belirlenmiştir. Bu dönemin en önemli tercümanları arasında An Shigao (安 世高/ 148-170), Dharmaraksa (筷法蘭/ 232-309), Dao An (道安/ 312 ya da 314-385), Kumarajiva (鳩摩

五方之民，言語不通，嗜欲不同。達其志，通其欲：東方日寄，南方日象，西方曰狄鞮，北方曰譯。

象胥掌蠻、夷、閩、貉、戎、狄之國使，掌傳王之言而諭說焉，以和親 之。若以時入賓，則協其禮，與其辭，言傳之。

Altı Hanedan Dönemi (六朝/ 220-589) olarak da bilinen bu dönem, Han Hanedanı'nın dağılması, Sui Hanedanı'nın kurulması arasında geçen dönemdir. Bu dönemde ilk olarak San guo, Wei (220-265), Shu (221-263), Wu (229-280) daha sonra Batı Jin (MS265-316), Doğu Jin (MS317-420), son olarak da Kuzey ve Güney Hanedanları (MS420-588) yönetime gelmiştir. 
羅什/ 350-409) ve Xuanzang (玄牀/ 602-664) yer almaktadır. Budist eserlerin tercümesi, Çin’in başlıca dinlerinden biri haline gelen Budizm’in yayılmasına katkıda bulunmuştur.

Cizvit misyonerlerin 16. ve 17. yüzyıllarda Katolikliği yaymak ve bilimi öğretmek için Çin’e gelmeleriyle ikinci çeviri patlaması dönemi yaşanmıştır. Yaklaşık 200 yl süren bu dönem, Batı dünyasında bilimin önem kazandığı bir dönem olarak bilinmektedir. Bu süreçte hükümetin ve Çin halkının kabulünü kazanmaya çalışan Cizvit misyonerler, Batı bilimini tercüme yoluyla tanıtmayı seçmişlerdir. Bilimsel eserlerin çevirileri modern Çin tarihine damga vurmuştur. Bu iki yüzyll boyunca en dikkat çekici başarılar, matematik, geometri ve astronomi gibi temel bilimlerin tanıtılmasıyla kazanılmıştır (Xiong, 1994).

20. yüzyll başı geç dönem Qing (清朝/ 1636-1912) Hanedanı'na gelindiğinde Çin, Sanskritçe yazıların çevirileri, Batı bilim ve teknoloji kitaplarının çevirilerinin ardından 16. yüzyıldan itibaren Batılı misyonerler tarafından başlatılan çevirilerle, 3000 ylllk tarihinde çeviri faaliyetlerinin üçüncü zirve dönemine tanık olmuştur. Yaşanan bu gelişmelerin tümü, Çin kültür ve zihniyetini derinden değiştirerek Çin üzerinde büyük bir etki yaratmış olsa da, geç dönem Qing çeviri patlaması çeşitli özellikleriyle diğerlerinden ayrılmaktadır. İlk olarak, bu süreçte üretilen çeviri kitapların miktarı, tartışmalı bir şekilde, Çinliler tarafından yazılan kitapların miktarını aşmıştır. Geleneksel Çin kurgusunda uzmanlaşmış Çinli bilim insanı A Ying’in (阿英) yaptığı bir tahmine göre, 1875-1911 ylları arasında 60o'den fazla yabancı eser çevrilip yayınlanmış ve toplam eserlerin neredeyse üçte ikisini çeviri eserler oluşturmuş̧tur. Ayrıca toplam 1170 eserden 618'inin siyasi ve eğitici romanlardan polisiye ve bilimteknoloji romanlarına kadar uzandığı belirtilmektedir (1957: 65).

İkinci olarak, bu süreçte çeviri faaliyetleri hem devlet destekli hem de piyasa odaklı olmuştur. Çin'in İkinci Afyon Savaşı'nda (1856-1860) başarısız olması, Qing yetkililerinin eğitim ve siyasi sistemlerdeki reformlarının başlangıcına işaret etmektedir. İki dil bilen yetkililerin eksikliğinden yakınan Qing merkezi hükümeti, 1862 yllında Pekin'de ilk tercüman eğitim okulu olan “Tongwen Guan (同文館/ Birleşik Öğrenme Okulu)” kurmuştur. Qing yetkililerine dış ilişkilerle ilgili temel bilgileri sağlamak için, bu okulun öğretmen ve öğrencileri tarafından çoğu uluslararası hukuk ve Batı ülkelerinin tarihlerine ait 200'den fazla kitap çevrilmiştir. Dönemin çevirmenleri özellikle, matematik, fizik, kimya, astronomi, jeoloji, mineraloji, askeri teknoloji üzerine odaklanmışlardır. Devlet destekli çevirilere ek olarak, gelişen özel yayınevleri, çevirmenleri finansal olarak destekleyerek Batı edebiyatının çevirisinin gelişmesini de büyük ölçüde kolaylaştırmışlardır. Guangzhou (广州) ve Shanghai (上海) gibi liman şehirlerindeki hızlı ticarileşmeyle birlikte, şehir sakinlerinin okuma ihtiyaçlarını karşılamak için gazete ve dergiler de yayınlanmaya başlamıştır. Batı edebiyatının çevirileri edebi dergilerin her sayısında tam anlamıyla yer almış, bazıları ise sadece çeviri eserler yayınlamışlardır (A, 1955: 187).

Üçüncü olarak, geç Qing döneminde Batı edebi çevirilerinin gelişimi, Çin milliyetçiliğinin yükselişiyle eş zamanlı olmuştur. Benedict Anderson'un gözlemlerini temel aldığı Avrupa uluslarının aksine Çin, geniş toprakları, farklı etnik kökenleri ve uzun kültürel geçmişi olan birleşik bir imparatorluk olarak kalmıştır. Geleneksel Han Çinlilerinin görüşüne göre, orta ülke anlamına gelen Zhongguo/ 中国 (Çin), coğrafi olarak dünyanın farklı topluluklarıyla çevrili en medeni merkezidir. Başka bir halkın konumu, Han Çin kültürüne ne ölçüde asimile olduklarına göre değerlendirilmiştir. Bu Çin-merkezciliği fikri, ölmekte olan Qing İmparatorluğu 19. yüzyılda Avrupalı sömürgecilerle karşı karşıya gelene kadar ciddi bir meydan okumayla karşılaşmamıştır. Çin kimliğinin krizi, birçok Çinliyi, farklı milliyetçilik türleri oluşturan etnik veya kültürel bir duruştan yeni kimlik kaynakları bulmaya zorlamıştır. Bu geçiş döneminde ise çeviri önemli bir rol oynamıştır. 
Tongwen Guan, kırk yıllık varlığı boyunca ve özellikle 1863-1898 yılları arasında ortalama 18.680 tael gümüşle, Qing hükümetinden istikrarlı bir fon sağlamayı başarmıştır. Bütçe 1898 yılında 34.894 tael ile zirveye ulaşmıştır ki bu Pekin'i korumaktan sorumlu bir ordu olan shenji ying 神機營 (Pekin Kara Kuvvetleri) tarafından alınan bütçeye neredeyse eşdeğerdir ( $\mathrm{Su}, 1985$ : 29-30). Başlangıçta sadece yabancı diller ve Konfüçyüs klasikleri üzerine dersler veren okul, daha sonra müfredatını modern bilimleri de içerecek şekilde genişletmiştir. Ancak, donanımına ve yenilikçi müfredatına rağmen okul, dış ilişkiler alanında uzman sağlama hedefini gerçekleştirememiştir. Su Jing'in hesaplamasına göre, 1879 yılında altı Çin elçiliğinde sadece on altı Tongwen Guan öğrencisi çalışmış; bu sayı, Çin elçiliklerinin sayısının neredeyse iki katına çıtı̆̆ı 1898 'de ise sadece on dokuza yükseltilebilmiştir (1985: 74).

Pek çok bilim insanı, Tongwen Guan'ın Çin'in modernleşmesi için yeni yetenekleri yetiştirmedeki başarısızlığını, Çinli aydınların Batı'ya, özellikle de onun bilim ve teknolojisine yönelik olumsuz tutumları ile açıklamaya çalışmıştır. Li Xinran (2015), Ding Zhiwei ve Chen Song (1995), metinsel çalışmalara öncelik veren Konfüçyüs geleneğinin, Çinli aydınların Tongwen Guan tarafından sağlanan bilimsel ve teknolojik eğitimi benimsemesini engellediğine inanmışlardır (182 \& 86). Jia Yongtang ise Tongwen Guan'ın başarısızlığının izini, geç Qing döneminde aydınlar arasında ortaya çıkan bir yabancı düşmanlığına kadar takip etmiş̧ir (2001: 33-34). Öte yandan Knight Biggerstaff daha makul bir şekilde, bu entelektüel atmosferin, yeterli öğrenci adayı bulamayan okul için ölümcül bir kabul krizi yarattığını savunmuştur (1961: 140-152). Gerçekten de, yabancı düşmanlığı duygusu, bilim ve teknolojiye yönelik küçümseme dönemin Çin’inde gerçektir ve Tongwen Guan'ın gelişimini etkilemiştir. Bununla birlikte, bu yaklaşımın altında, şimdi yeniden incelenmekte olan bir varsayım, hareketsiz bir Çin ile ilerici Batı arasındaki ideolojik farklılığın, birincinin ikincisinin bilim ve teknolojisini benimsemesini engelleyen en büyük engel olduğu varsayımı yatmaktadır. Son araştırmalar, Çin-Batı ve Konfüçyüsçü-bilimsel eğitim arasındaki ikiliğin, modern Çin'in yörüngesini tartışmak için bir çerçeve olarak itibarını kaybettiğini göstermektedir. Çinli okuryazarların bilim ve teknolojiye ilgisiz olduğu varsayımına, Benjamin A. Elman'ın, erken ve geç Qing döneminde aydınların astronomik ve matematiksel çalışmalara olan ilgisinin, kanıtsal bilime doğru entelektüel dönüşün bir sonucu olarak yeniden canlanmasına ilişkin çalışmasıyla meydan okunmuştur (1990: 37-85). Cizvitlerin Ming takviminin revizyonuna yaptıkları önemli katkı, aynı zamanda, Çin geleneğinin önemli bir parçası olarak Batı biliminin başarılı entegrasyonunu göstermeye hizmet etmektedir (Elman, 2005: 61-68). Yine de Çin-Batı karşıtllğ̆l, Ming takviminin revizyonunu engellemeyen ideolojik farklılığın neden Tongwen Guan'ın gelişimi için çözülemez bir engel haline geldiğini açıklamakta başarısız olmaktadır.

Tongwen Guan'ın sınırlı başarılarını açıklamak için Çin-Batı ikilemini kullanmak: dış faktörlerin okul üzerindeki etkisine çok fazla vurgu yapılması, okulun yapısına ve fiili işleyişine yeterince dikkat edilmemesi gibi istenmeyen bir sonuca yol açmıştır. Bazı bilim insanları, bu kör noktayı önceki çalışmalarda fark etmişler ve bu nedenle de okulu incelerken kurumsalcı bir yaklaşım benimsemeye başlamışlardır. Örneğin Chen Xiangyang (陳向陽), Wanqing jingshi Tongwen Guan yanjiu (晚清京師 同文館研究) isimli çalışmasında, okulun kırk yılı aşkın süredir yaptığı bir dizi örgütsel reformun olumlu bir değerlendirmesini sunmuş ve okulun kademeli olarak modernize edildiği sonucuna varmıştır (2004). Bu yaklaşım, Çin ile Batı arasındaki ideolojik eşitsizliğin etkisinin olası abartılmasından kaçınarak, Tongwen Guan'ı incelemek için yeni bir bakış açısı sunmuştur. Chen'ın Tongwen Guan'ın övgüye değer çabalarını anlatan anlatımı ise merak uyandıran bir soruyu gündeme getirmiştir: Neden üstlenilen tüm kurumsal yenilikler sonunda istenen sonuçları üretemedi? 
Konunun daha iyi anlaşılması için Tongwen Guan ile Zongli Yamen (總理衙門 /Tüm Uluslardan Sorumlu Qing Ofisi, dış politikadan sorumlu organ) arasındaki etkileşimin derinlemesine tartışılması gerekmektedir. Bu çalışma, okulun Zongli Yamen'in kuklası olduğu (Lü \& Zhang, 1988: 94) şeklindeki eski varsayımı kabul etmek yerine, 1867'de karşılaştığı ve reformları başlatmasını sağlayan başarısızlıktan sonra okulda ortaya çıan, aşağıdan yukarı Çin'in modernleşmesi yolunda ihtiyaç duyulan personeli üretmek için firsatlar yaratan kurumsal dinamik biçimini ele almaktadır. Çalışma sonucunda, reformların umut verici sonuçlarının ne yazık ki Tongwen Guan'ın kurumsal zayıflığı ve Çin'in Birinci Çin-Japon Savaşı'ndaki yenilgisini izleyen siyasi durum tarafından kısıtlandığını iddia etmeye devam edilmektedir.

\section{Tongwen Guan'ın kuruluşu}

Çin'in Birinci ve İkinci Afyon Savaşlarında (1839-1842 ve 1856-1860) aldığı acı yenilgi ve Taiping İsyanı'nın (1851-1872) bastırılmasında sergilenen Batı silahlarının muazzam gücü, bazı ileri görüşlü okuryazarları Batılıların askeri teknoloji üstünlüğüne ikna etmiştir. Bu nedenle aydınlar, Çin'i güçlendirmek için Batı bilim ve teknolojisini benimsemeyi savunmuşlardır. Ancak bunu yaparken Çin'in siyasi veya sosyokültürel yapılarını değiştirme niyetinde olmamışlardır. Sonuç olarak, bu aydınların çabaları, 19. yüzyılın ikinci yarısında, Feng Guifen'in da iddia ettiği gibi, karakteristik doktrinleri Çin öğrenimini desteklemek için Batı bilgisini benimsemek olan "Kendi Kendini Güçlendirme Hareketi" olarak adlandırılan bir dizi kurumsal reforma dönüşmüştür (1967: 57). Batı bilgisini ithal etme ihtiyacı, Qing hükümetinin Afyon Savaşları'ndan sonra açlan antlaşma limanlarında yabancı devletlerle iletişimindeki artışla birleştiğinde, daha önce Uzak Bölgelerin İdaresi Kurulu Bakanlığı tarafından ele alınan dış ilişkilerle ilgilenmek için bir devlet kurumu kurma ihtiyacını gündeme getirmiştir. Prens Gong olarak da bilinen Yixin (奕䜣 /1833-1898), 13 Ocak 1861'de Qing Çin'inde dışişleri bakanlığına eşdeğer olan Zongli Yamen'in kurulmasını önermiş ve Mart 1861'de kuruluşunu onaylamıştır.

Zongli Yamen'in kurulmasını öneren yazısında Yixin, Çin'deki mütercim-tercüman eksikliğinden kaynaklanan iletişim sorunlarını çözmek için bir yabancı dil okulu kurma fikrini anlatmıştır. Yeni okulda dil öğretmek için Shanghai ve Guangdong'dan İngilizce ve Fransızca konusunda uzmanlığı olan dört Çinli eğitmenin işe alınmasını önermiştir (Jia, 1970: 17). Onun önerisinde açılkanan okul 1862'de asıl olarak Tongwen Guan ismiyle kurulmuş ve ilk dersleri İngilizce olarak verilmiştir. Daha sonra Fransızca, Rusça ve Japonca da müfredata eklenmiştir. Aslında Yixin, 1708'de kurulan bir devlet enstitüsü olan Qing'in Rus Dil Okulu'nu modellemiş̧ir. Tongwen Guan'ın altı ilkesini formüle ederken de Rus Dil Okulu'nun politikalarına atıfta bulunmuştur: 1) 15 yaşın altındaki Mançu öğrencilerini kabul etmek; 2) hükümetin doğrudan denetimi altında faaliyet göstermek; 3) aylık, üç aylık ve yıllık incelemeler yapmak; 4) seçkin öğrencilere resmi rütbeler vermek ve mevcut hükümet boşluklarını doldurmalarına izin vermek; 5) sırasıyla Konfüçyüs klasiklerini ve yabancı dilleri öğretmek için Han Çinli ve yabancı eğitmenleri işe almak ve 6) öğrencilere aylık üç tael gümüş ödeneği sağlamak (Bao, 1971: 29-35).

Tongwen Guan'ın işleyişi, bazı ayrıntılarıyla Rus Dil Okulu'nunkinden farklılaşmıştır. Okul, Zongli Yamen tarafından yönetilip finanse edilmiştir. Zongli Yamen'in ana gelir kaynağı da gümrük gelirlerinden geldiğinden, 1861 ve 1911 yılları arasında Çin İmparatorluğu Deniz Gümrük Hizmetleri genel müfettişi Robert Hart (1835-1911), özellikle Tongwen Guan'ın gelişimi üzerinde büyük bir olumlu etki yaratmış ve okulda personel maaşları, işe alımlar, sınavlar vb konularda söz sahibi olabilmiştir.

Bu farklılıklara rağmen, Tongwen Guan'ın yönetmeliğinde, Rus Dil Okulu'ndan miras aldığı temel yapı değiştirilmemiştir: hükümet tarafından sıkı bir şekilde kontrol edilmiş ve neredeyse hiçbir kurumsal 
bağımsızlı̆̆ı olmamıştır. Daha da önemlisi, müfredatında sadece yabancı dil kursları ve Konfüçyüs klasikleri öğretildiği için Rus Dil Okulu'nun bir kopyasından başka bir şey olamamıştır. Bu nedenle, başlangıçta, Kendini Güçlendirme Hareketi savunucuları tarafından kurulan en eski devlet okulu olan Tongwen Guan, Çin'de zaten var olan mesleki yabancı dil okullarının yalnızca bir kopyası olmuştur. 1869'a kadar okulun örgütsel dinamik değişimi, prototipinden önemli ölçüde farklı olan modern bir okula dönüşebilecek şekilde olmamıştır.

\title{
Öklid çevirisinin tamamlanması (1865)
}

On dokuzuncu yüzyll Çin'inin eğitim reformlarını teşvik eden yetkililerinden belki de en göze çarpanı Zeng Guofan (曾国藩 / 1811-1872)dır. Taiping İsyanını bastırmada etkili bir general olan Zeng, reform hareketine de katılmış olan bir bilim insanıdır. Zeng, isyancılara karşı yürüttüğü seferin sonuna doğru, orduda emrinde çalışan bilgin Li Shanlan'la (李善蘭/ 1810-1882) yakınlaşmıştır. Bu süreçte Li, Zeng'dan "matematikçiler için vazgeçilmez" ve "basılmazsa kaybolacak" olan bir kitabın basımına sponsor olmasını istemiştir. Bu kitap, Öklid'in Elementler rinin tamamlanmış bir çevirisidir. Ming Hanedanından Xu Guangqi (徐光啓/1562-1633), Matteo Ricci'nin yardımlarıla Elementler'in ilk altı bölümünün diktelerini kopyalamış olsa da, çalışma yüzyıllar boyunca eksik kalmıştır. 1851'de Li, son dokuz bölümün çevirisini bitirmek için Alexander Wylie ile birlikte çalışmıştır. Çalışmaları Sung-kiang'da yayınlanmış, ancak kısa süre sonra isyan sırasında tahta baskı blokları yakılmıştır. Daha sonra Li, bu kitabı yeniden basmak için Zeng'dan yardım istemiş̧ir (Nanqiu, 2006: 258-260).

Taiping İsyanının çatışmaları sırasında Zeng, yabancı paralı askerlerin kullandıkları silahların etkinliğine tanık olmuş ve onları üretebilecek teknolojiye karşı bir hayranlık geliştirmiştir. Savaş sanatıyla doğrudan ilgili olduğu için de Çin okullarında Batı biliminin araştırılmasının aktif bir destekçisi olmuştur. Zeng, Elementler'in ilk Çince baskısında Ricci'nin önsözünü okuduğunda, matematiğin önemine ilişkin umutları kuşkusuz doğrulanmıştır. Ricci bu önsözünde, pratik bir bilim olarak aritmetiği ayırt ederek, astronomi, takvim yapımı, tıp, coğrafya ve ticaret alanlarında geometrinin Çin toplumu için önemini belirtmektedir. Özellikle, askeri işlerin yürütülmesinde geometrinin gerekliliğini şu ifadeleriyle vurgulamıştır:

\begin{abstract}
"Askeri işler bir ulusun en önemli birimidir, çünkü ulusun güvenliği onlara bağlıdır... Bu nedenle, bilgili ve cesaretli bir general, her şeyden önce geometri bilgisine sahip olmalıdır, aksi takdirde bilgisi ve cesareti pratik değerden yoksun olacaktır (Peake, 1932: 7).”
\end{abstract}

Ricci daha sonra önsözünde, küçük bir ulusun generalinin, geometri bilgisini kullanarak daha büyük bir ulusu nasll fethettiğine dair de bir örnek vermiştir.

Zeng, Öklid'in Geometri Öğeleri'nin gözden geçirilmiş bir baskısının, 1865'te Nanjing'deki (南京) karargahından yayınlanmasını emretmiştir. Ricci, Xu, Wylie ve Li tarafından yazılan çevirilerde yer alan önceki önsözlere Zeng, Çin'deki geçmiş matematik eğitimiyle ilgili görüşlerini sunduğu kendi önsözünü eklemiştir:

"Geleneksel matematiğimize göre, her bölüm adını belirli (pratik) bir işlevden alır. Öğrencilerin hepsi problemlerini çözerken bu kurallara uyarlar. Ancak hayatları boyunca matematiği sadece nasıl yapılacağını bilerek kullanırlar, neden yapıldığını bilerek değil. Bu nedenle matematiği çok zor bir konu olarak görüyorlar çünkü kafaları karışıyor, yöntemi biliyorlar ama ilkelerini bilmiyorlar... Öte yandan Öklid'in Geometrisi yöntemle değil, ilkelerle ilgileniyor (Peake, 1932: 5).”

Matteo Ricci'nin geometriyi ilk dikte etmesinin üzerinden geçen iki yüzyll içinde, diğer misyonerler de başka bilimsel çalışmaları Çinceye çevirmişlerdir. Ancak, bunlardan yalnızca on iki tanesi matematikle 
ilgili olup, hiçbiri Öklid'i tamamlamamıştır (Cordier, 1901). Kısacası, Çin’in entelektüel ikileminin en kritik döneminde, imparatorluğun ünlü ve geniş çapta takdir edilen bir yetkilisi olan Zeng, tüm Batılı matematik çalışmalarının en etkilisinin yayınlanmasını onaylamıştır. Onun bu eylemi, reform savunucularının ve özellikle matematiksel çalışmaların savunucularının güçlendirilmesini sağlamıştır.

\section{Tongwen Guan'daki astronomi ve matematik bölümleri (1865)}

Kendi Kendini Güçlendirme Hareketi'nin ilk yıllarında Çin, fazla miktarda satın alınan Batı tarzı silah üretim makinelerinin kurulduğu Jiangnan Arsenal ve Foochow Deniz Koleji ${ }^{6}$ gibi bir dizi devlete ait silah üretim kuruluşu kurmuştur. Kendi Kendini Güçlendirme Hareketi’ni savunanlar kısa sürede Batı silahlarına sahip olmanın Çin'i güçlendirmek için tek başına yeterli olmadığını anlamışlar ve Batı bilimi ve teknolojisi ile kendi makine ve mühimmatlarını üretmenin anahtarına hâkim olmak istemişlerdir (Bao, 1971: 3-4). Bu doğrultuda yabancıların eğitmen olarak işe alındığı Foochow Deniz Koleji gibi yeni okullar kurmuşlardır. Bu aydınların reforma edilmiş gündemleri, Tongwen Guan'a ilişkin vizyonlarını da etkilemiştir. Deneyimli bir hükümet yöneticisi olan Feng Guifen (馮桂芬), bu yeni okulun konseptlerini kabul etmiş, ancak müfredatın matematiği içerecek şekilde genişletilmesini istemiştir (1885: 38). 1863 yllının Haziran ayında, tanınmış bir memur olan Li Hongzhang (李鴻章/ 1823-1901) da, Tongwen Guan'ın kurulmasını desteklemiş ve benzer bir okulun Shanghai'da da açılmasını istemiştir. Onun bu isteği, anıtında sekreteri Feng Guifen tarafından kaleme alınmış ve matematiksel çalışmaların gerekliliğine ilişkin her iki adamın duyguları şu ifadelerle birleşmiştir: "Batılı bilim insanlarının silah yaptıklarında, referans olarak matematiği kullandıklarını öğrendim.” Bu anıta yanıt olarak, benzer dil okulları Shanghai (1863), Kanton bölgesi (1864) ve Fuzhou'da (1866) kurulmuştur. Bu okullar, hükümetin modern eğitime yönelik ilk girişimlerini temsil etmiştir.

Tongwen Guan'ı Batı bilim ve teknolojisini Çin'e tanıtmanın bir aracı olarak gören Yixin de 11 Aralık 1866'da ona bir Astronomi ve Matematik Bölümü eklenmesini şu ifadelerle önermiştir:

"Batı'nın makineleri, vapurları, ateşli silahları ve askeri taktiklerinin hepsinin kaynağı matematik bilimindedir. Şimdi Shanghai'da ve başka yerlerde buharlı gemilerin inşasına başlandı; ama korkarız ki, yüzeysel bir bilgiyle yetinirsek ve işin aslına inmezsek, bu tür çabalar sağlam bir başarı sağlamayacaktır... Eğer matematiksel hesaplamaların, fiziksel araştırmaların, astronomik gözlemlerin, motorların inşasının, suyollarının mühendisliğinin gizemlerinde ustalaşabilirsek, imparatorluğun gücünün istikrarlı büyümesini sadece ve sadece bununla sağlayabiliriz (Papers Relating to Foreign Affairs, 1867/ 1868: 473-474)."

28 Ocak 1867 'de Yixin bilimsel çalışmalar için yeni bir öneride bulunmuştur. Bu daha ayrıntılı önerisinde, Batı biliminin köklerini gerçekten eski Çin matematiğinden ödünç aldığını, dolayısıyla bu bilimi öğrenmenin yabancı bilgisinin edinilmesi olmayacağını açıklayarak saraydaki milliyetçi kesimin boşuna gurur yaptığını ileri sürmüştür (Peake, 1932: 4). Yixin'in bu açıklaması günümüzde, "Xixue Zhongyuan(西学中源)" olarak adlandırılan, “Batı biliminin Çinli kökenleri” iddiasına denk gelmektedir. Böylece Yixin, dönemin Çin’inde Batı bilimine karşı olanları, bilimin aslında sadece Batı'ya ait olmadığını, köklerini Çin’in eski metinlerinden aldığını ileri sürerek ikna etmeye çalışmıştır. Ayrıca önerisinde, saltanatı sırasında matematik çalışmalarını teşvik eden İmparator Kangxi (康熙帝/1662Fuzhou veya Mawei Arsenal olarak da bilinen Foochow, Qing İmparatorluğu tarafindan Kendi Kendini Güçlendirme
Hareketi kapsamında kurulan birkaç tersaneden biridir. 
1723) ve Öklid'in Elementler'inin tamamlanmış bir çevirisini henüz yayınlamış olan Zeng Guofan'ı, matematiğin babaları olarak imparatorluğun iki kahramanı şeklinde göstermiştir.

Yixin, İngilizce, Fransızca ve Rusça bölümlerinden farklı olan iki yeni bölüm için bir dizi kabul politikası tasarlamıştır. Yeni bölümlere kabul edilme sadece genç Mançu öğrencileriyle sınırlı tutulmamış, aynı zamanda Hanlin Akademisi'nde veya Pekin dışında eyalet sivil sınavını geçen veya İmparatorluk Akademisi'ne kayıtlı olan 20 yaş üstü Mançu veya Han Çinlilerini veya her ikisinde de çalışan düşük rütbeli memurları da içermiştir (Bao, 1971: 44-48). Yixin ayrıca bu öğrenciler için yeni bir müfredat belirlemiştir. Bunların yabancı dil okumak zorunda olan diğer bölümlerdeki öğrencilerin aksine, özellikle astronomi ve matematik üzerine yoğunlaşmalarına olanak sağlanmıştır (Bao, 1971: 48). Bu doğrultuda yeni politikalarla daha yetenekli öğrencileri işe almak amaçlanmıştır. 1866'da Yixin, Klasik Çincede henüz akıcı olamayan genç Mançu öğrencilerini hem yabancı dilleri hem de bilimsel konuları öğrenmek için okula kaydettirmenin zorluğunu fark etmiştir. Bu nedenle de umutlarını zaten konuda ustalaşmış olan diğer öğrencilere bağlamıştır.

Yixin'in önerisi, bir Shandong Eyaleti Denetçisi olan Zhang Shengzao (張盛藻/1819-1896) ve bir Hanlin Akademisi Başkanı ve önde gelen Neo-Konfüçyüsçü bilgin olan Woren (倭仁 /1804-1871) tarafından kısa sürede Tongwen Guan'ın ulusal boykotuna tırmanan protestolara yol açmıştır. Bu iki milliyetçi aydın okula üç konuda saldırmışlardır. İlk olarak bilim ve teknolojinin Çin'i güçlendirmek için çok da önemli olmadığını savunmuşlardır. Yixin astronomi ve matematiği Batı'nın Çin üzerindeki askeri üstünlügünün anahtarı olarak görürken, Zhang ve Woren güçlü bir devletin sırrının sadece Konfüçyüs klasiklerinde bulunabileceğine inanmışlardır (Bao, 1971: 15-16). Ayrıca Woren, yeni matematik ve Batı ile olan ilişkisine dair şüphelerini dile getirmiş ve böyle bir eylemin tehlikelerine karşı imparatora şu ifadelerle uyarıda bulunmuştur:

\begin{abstract}
“Altı sanattan biri olan matematik, gerçekten de Âlimler tarafindan şer'î hükümde belirtildiği gibi öğrenilmeli ve değersiz bir konu olarak görülmemelidir. Ama kölenizin bakış açısına göre astronomi ve matematik çok az işe yarar. Bu konular Batılılar tarafindan düzenli çalışmalar olarak öğretilecekse tehlike büyük olacaktır... Kulunuz, milleti kurmanın yolunun, kuvvet ve düzene değil, hak ve adalete önem vermek olduğunu öğrenmiştir... Astronomi ve matematik öğretilecekse, kapsamlı bir araştırma ile bu teknikte ustalaşmış biri bulunmalıdır. Neden barbarlarla ${ }^{7}$ sınırlı ve neden barbarlardan öğrenmek gerekiyor (IWSM 47, 1929/1931: 24)?”
\end{abstract}

İmparator Yixin, Zongli Yamen üzerinden onların bu görüşlerini adeta çürüten cevaplar vermiştir. Yixin, onlara geçmişte yabancıların elinde maruz kaldığı aşağılanmaları hatırlatmıştır. Başkent tehlikedeyken şahit olduğu durumu "âlimler ve memurlar ya ellerini kollarına koyarak ayağa kalktılar ya da şaşkınlık içinde kaçtılar" ifadeleriyle anlatmıştır (Clyde \& Beers, 1966: 153). Yixin konuşmasına yabancıların gücünü açıklayarak devam etmiştir:
"Yabancıların zafer elde etmek için başvurdukları başlıca araç, her şeyden önce buharlı gemi ve ateşli silah kullanmaktır. Avrupalılar ateşli silahlar yaparken ne kadar sermaye kullandıklarını umursamadıklarından ve ateşli silahların kökleri astronomi ve matematikte olduğundan, böylece silahları akıllıca kullanabilir ve harika bir şekilde hedefi vurabilir duruma gelmişlerdir... Diğer görevlilerimizin hepsi de akıllı üretim yöntemlerinin matematikle başlaması gerektiği konusunda hemfikirdirler... (IWSM 48, 1929/1931: 2)"

Zhang ve Woren'in görüşleri genellikle Çinli aydınlar arasında bilim ve teknolojiye yönelik mevcut bir küçümsemeyi temsil ettiği şeklinde yorumlanmıştır. Konfüçyüs klasiklerinin incelenmesinde bilimsel ve teknolojik konulara gerçekten öncelik vermiş olsalar da, bu onların ikincisine ilgi duymadıkları veya 
okul müfredatına dâhil edilmelerini reddettikleri anlamına gelmemektedir. Erken Qing'de kanıtsal bilimin ortaya çıkışı, aydınların astronomi ve matematik çalışmalarına olan ilgisinin yeniden canlanmasına katkıda bulunmuş ve bu 1750'den sonra kurulan birçok akademinin müfredatına nüfuz etmiştir (Elman, 1990: 120-121). Örneğin, önde gelen bir Çinli bilgin olan Ruan Yuan (1764-1849) tarafından kurulan iki okul olan Gujing Jingshe (詁經精舍) ve Xuehai Tang (學海堂), müfredatlarına astronomi, matematik ve coğrafyayı eklemişlerdir. Ayrıca, on dokuzuncu yüzyılın ortalarında, İngiliz misyonerler, Batılı bilimsel ve teknolojik bilgilerin Çinceye çevrildiği London Missionary Society Press'i de kurmuşlardır. Li Shanlan ve Wang Tao (王秤 /1828-1897) dâhil olmak üzere birçok Çinli aydın, bu kurum için çevirmen olarak çalışmışlardır. Bu durum, Qing aydınlarının bilim ve teknoloji yerine Konfüçyüsçü klasikleri incelemeye öncelik vermiş olmalarına rağmen, Tongwen Guan'ın müfredatına bilimsel ve teknolojik konuların eklenmesine karşı çıkmak için güçlü bir teşvikleri olmadığını göstermektedir. Bu nedenle, onların okula karşı düşmanlıkları, muhtemelen, Çinli okuryazarların bilim ve teknolojiye olan ilgisizliği dışındaki faktörler tarafından kışkırtılmıştır.

Muhafazakâr aydınların ikinci itirazı, Çinlilerin Batılılardan öğrenmesi gerektiği fikri olmuştur. Yixin, matematik ve astronomi öğretmek için yeterli sayıda Çinli eğitmen bulmanın imkânsızlı̆̆ından, Batılı eğitmenleri işe almanın uygun olduğuna dikkat çekmiştir. Ayrıca Tongwen Guan'da, öğrenciler onu öğretebilecek kadar Batılı bilgi edindikten sonra artık Batılı eğitmenleri işe almayacağına söz vermiştir (Bao, 1971: 14-15). Zhang Shengzao muhalefetini dile getirmeden önce bile, Yixin zaten Zou Boqi (鄒伯 奇 /1819-1869) ve Li Shanlan'ı matematik öğretmeleri için işe almaya çalışmıştır. Muhafazakâr aydınlar ise aksine, Batılıları düşman olarak görmüş ve Çinli öğrencileri Hıristiyanlığa çevireceklerine inanmışlardır (Bao, 1971: 24-25). Aydınların Batılı eğitmenleri reddetmesi ilgi çekici olmuştur. Gerçekten de, Qing okuryazarları arasında misyonerlik faaliyetlerine karşı yaygın bir antipati vardır, ancak Rus Dil Okulu zaten bunun için bir emsal oluşturmuş olduğundan, 1867'de Batılı eğitmenleri işe almaya yönelik ani muhalefet artışı tek başına yabancı düşmanlığı hissini açıklayamamaktadır. Benzer şekilde, hiçbir okuryazar, 1867'den önce Tongwen Guan'da Batı dillerini öğretmek için Batılı eğitmenlerin işe alınmasına karşı çıkmamıştır. Bu nedenle, yabancı düşmanlığı muhtemelen diğer faktörler tarafından harekete geçirilmiş ve okuryazarların Tongwen Guan'a karşı düşmanlı̆̆ının doğrudan nedeni değildir.

Muhafazakâr aydınların Tongwen Guan'a saldırısının altında yatan temel neden: aydın öğrencilerin Astronomi ve Matematik bölümlerine kabul edilmesi olarak üçüncü şıkta görülebilmektedir. Zhang Shengzao, Zongli Yamen tarafından vaat edilen maaşların ve kariyer beklentilerinin okuryazarların ahlaki bütünlüğünü bozduğunu ve geleceklerini tehlikeye attığını iddia etmiştir (Bao, 1971: 15-16). Zhang'ın eleştirisi, önerilen kabul politikasından doğan yetkilileri seçmeye yönelik yeni yöntem konusundaki endişesini ortaya koymaktadır. Yinxin'in planına göre, Tongwen Guan'da üç yılda bir yapılan sınavda yüksek puanlar alan öğrencilerin hükümetteki boş yerleri doldurmalarına izin verilecektir (Bao, 1971: 44-48). Tongwen Guan'ın 1862 yönetim bildirisinde yer alan, öğrencilerin hükümetteki boş kadroları doldurmalarına izin vermek aslında yeni bir politika değildir. Asıl sorun, böyle bir ödüle hak kazanan öğrencilerin kategorisidir. 1862 politikası, yalnızca bürokrasiye giden ana yolu sivil sınavdan geçmeyen Mançu öğrencilerine uygulanıyordur, bu nedenle hükümet görevlerini almak için ona güvenenler üzerinde neredeyse hiçbir etkisi yoktur. Buna karşıllı, Yixin'in Han Çinlilerini Astronomi ve Matematik bölümlerine kabul etme önerisi, Tongwen Guan'ın bürokrasiye sivil sınavlarla giren veya girmeyi planlayanlar için bir tehdit oluşturacağı anlamına gelmektedir. Çin'de memuriyet sınavının sıralamaları büyük ölçüde kişinin ilk atamasını ve hatta bir kişinin hayatında alabileceği en yüksek görevi belirlemektedir. Bununla birlikte, Tongwen Guan'ın yeni kabul politikası, Han Çinlilerinin kariyer beklentileri üzerindeki sıralama sisteminin kısıtlamalarını atlamasına izin verecek alternatif bir 
kanal yaratmıştır. Okul ayrıca daha düşük rütbeli yetkililere terfi için bir kısa yol sağlamıştır. Sonuç olarak, okulun yeni kabul politikası geleneksel sistemi tehdit ediyor olarak algılanmış ve bu nedenle muhalefete maruz kalmıştır.

İmparatoriçe Cixi (慈禧太后/ 1835-1908) ve İmparatoriçe Ci'an (孝貞顯皇后/ 1837-1881), Yixin'in yanında yer almış ve Tongwen Guan'ın yeni politikaları üzerindeki anlaşmazlığa son vermişlerdir (Bao, 1971: 16-17). Onların destekçi faaliyetleri, Astronomi ve Matematik bölümlerinin kurulmasına olanak sağlamıştır. Buna rağmen, bazı aydınların Ortodoks kariyeri yolunda bir tehdit olarak algılanan okul, kaçınılmaz olarak ulusal bir ret ile karşı karşıya kalmıştır. 1867 yılında sınava gerçekten sadece yetmiş altı kişi girmiştir (Bao, 1971: 30-31). Zongli Yamen, bu küçük başvuru havuzundan otuz öğrenciyi kabul etmiş, ancak yirmi tanesi, yıllık sınavdaki yetersiz performansları nedeniyle kısa süre sonra ihraç edilmiştir (Bao, 1971: 35-36). Bu başarısızlıkla karşı karşıya kalan Zongli Yamen, öğrencileri bilim ve teknolojide uzman olarak yetiştirme planından vazgeçmek zorunda kalmıştır.

1867 gerilemesinin sonraki yılları Tongwen Guan'ın gelişimi üzerinde önemli bir etkisi olmuştur. Bir yandan, okuryazarların Tongwen Guan'a karşı düşmanlığı, okulu kabul edebileceği en iyi öğrencilerden mahrum etmekle kalmamış, diğer yandan genç Mançu öğrencilerinin işe alınmasını da etkilemiştir. Bu kabul sorunu, okulun yeni bir kabul politikası benimsediği 1880'lerin sonlarına kadar okulu etkilemeye devam etmiştir. Öte yandan, "başarısızlık", Tongwen Guan'ın gelecekteki gelişimi için de bir kapı açmıştır. Zongli Yamen, daha sonra okul müfredatının genişletilmesi için temel oluşturan Astronomi ve Matematik bölümlerini korumuştur. Daha da önemlisi, kabul başarısızlı̆̆ı, sonraki reformları başlatmak için ana güç haline gelen kurumsal dinamiklerin ortaya çıması için alan yaratan Zongli Yamen'in okula olan ilgisini azaltmıştır.

\section{Tongwen Guan'in restorasyonu}

Tongwen Guan ilk yıllarında Zongli Yamen'in sıkı kontrolü altında kalmıştır. Tüm idari personeli, okulun müdürü ve müdür yardımcısı da yalnızca ikincil görevlerde bulunan Zongli Yamen memurlarından oluşturulmuştur. Zongli Yamen ayrıca, okuldaki fakültenin hiçbir söz hakkının olmadığı öğrenci kabullerini, rutin sınavları, öğrenci maaşlarını ve fakülte işe alımlarını da dikte etmiştir. Bu durum 1867 kararlarının kabulünden sonra değişmiştir. Böylece bir yandan 1862'de on olan kayıtlı öğrenci sayısı 1867'de kırkın üzerine çıkarken, diğer yandan idari personelin kaldırabileceğinden daha fazla iş yükü oluşmuştur. Bu duruma rağmen okula olan ilgisini kaybeden Zongli Yamen, hemen yeni bir personel atamasında bulunmamıştır. Örneğin, 1869'da emekli olan ilk Tongwen Guan yöneticisi Xu Jiyu'dan (徐繼蕃/ 1795-1873) sonra, 1889'a kadar yeni bir komisyon üyesi atamasında bulunulmamıştır (Zhongguo shixuehui, 1961: 67-68). Bu idari personel eksikliği de okulun rutin işleyişini bozmuştur. Tongwen Guan'daki yabancı eğitmenlerden biri olan Michael John O'Brien, "fakülte şimdi var, ama ismen var" şeklindeki açıklamasıyla bu durumdan yakınmıştır (1870).

1867'den sonra Tongwen Guan'da ortaya çlkan iktidar boşluğu, Robert Hart'ın oradaki etkisini artırmıştır. Hart günlüğüne bu okulda, Çin İmparatorluğu Deniz Gümrük Hizmetlerindeki genel müfettişlik görevindeki gibi yetkiye sahip olduğunu yazmıştır (Wang, 1987: 367-368). Okulun tüzüğü müfettişin buradaki yargı yetkisini belirtmese de, Hart'ın kişisel mektupları, okulun gelir-gider kontrolü üzerinde söz sahibi olduğunu ileri sürmektedir ( $\mathrm{Su}, 1985: 24)$. Hart ayrıca okulda yabancı eğitmenlerin işe alınmasında da yetki sahibi olmuştur. Tongwen Guan öğrencilerinden biri olan Qi Rushan (齊如山/ 1875-1962)'a göre, yabancı eğitmenler haleflerini tavsiye edemezdi ve yeni eğitmenlerin Hart tarafından 
seçilmesi gerekiyordur (Qi, 1998: 32). Yixin'in 1866'daki anıtlarından birinde, yabancı eğitmenleri işe almak için Hart'a güvendiği de belirtilmiştir (Bao, 1971: 3-4).

Hart'ın Tongwen Guan'daki etkisi, Hu Daicong gibi bilim insanları tarafından bir emperyalist müdahale biçimi olarak eleştirilmiştir (1997: 44). Ancak bu büyük ölçüde haksız bir suçlamadır, çünkü Zongli Yamen çekildiğinde okulu işler durumda tutan Hart olmuştur. Onun çabaları, okulun 1877'ye kadar on eğitmeni elinde tutmasına yardımcı olmuş ve bu da müfredatının genişletilmesini sağlamıştır (Zhu, 1983: 37-41). Buna ek olarak, Hart ayrıca Tongwen Guan öğrencilerini yabancı ülkeleri ziyaret eden Çinli yetkililerin maiyetinin bir parçası olarak yurtdışına gönderme emsalini de oluşturmuştur (Bao, 1971: 12). Bu staj şekli daha sonra okulda geleneksel bir uygulama haline gelmiş ve Tongwen Guan öğrencilerinin iş bulmasında önemli rol oynamıştır.

Hart'ın Tongwen Guan'a en büyük katkısı, Türkçe karşllı̆̆ “genel eğitmen” olan zong jiaoxi (總教習) konumunu belirleme önerisi olmuştur. Okulun tüm yönetici personeli diğer kurumlarda müdürlük görevlerinde bulundukları için okulun rutin işleyişinde aktif rol oynayamamışlardır. İki müfettiş yardımcısı sırayla okulda ikamet etseler de, ne yabancı diller ne de Batı öğrenimi hakkında bilgileri olmamıştır. Okulun genişlemesi yeni bir yönetim pozisyonu olan zong jiaoxi'nin yaratılmasını gerektirmiştir.

Tongwen Guan yönetmeliğinde zong jiaoxi'nin sorumluluğu veya bürokratik rütbesi belirtilmese de, Daqing Huidian (大清會典) ${ }^{8}$ ve Zongli Yamen'in direktifleri yönetmelik hakkında bazı ipuçları vermektedir. İlkinin kayitlarına göre, zong jiaoxi, okulun yönetimi ile ilgili herhangi bir teklifi, başmüfettişten onay alacak olan müfettiş yardımcılarına sunmak zorundadır (Zhu, 1983: 31). Bu düzenleme, zong jiaoxi'nin hem müfettiş yardımcllarına hem de başmüfettişe tabi olduğunu ima etmektedir. Başmüfettiş, okulun rutin yönetiminde yer almadığı için politika girişimlerinden yoksun olduğundan, kontrolü zong jiaoxi ve müfettiş yardımcıları elinde tutmuştur. Bu arada, zong jiaoxi ismen müfettiş yardımcısına bağlı olmasına rağmen, iki görev pratikte hiyerarşik değildir. Zongli Yamen'in bir direktifi, zong jiaoxi'nin hem akademik işleri hem de yabancı fakültenin yönetimini denetlediğini belirtmiştir (Zhu, 1983: 149). Daqing Huidian'de, müfettiş yardımcılarının Çinli eğitmenler ve Çin müfredatıyla ilgili işlerden sorumlu olduğu belirtilmiştir (Zhu, 1983: 31). Ancak, zong jiaoxi ve müfettiş yardımcılarının sorumlulukları örtüşmediğinden ikincisinin birinciyi kontrol etmesi zor olmuştur. Ayrıca, Hart zong jiaoxi'nin atanmasından sorumlu olduğu için, müfettiş yardımcıları onu görevden alarak zong jiaoxi'nin yetkisini kısitlayamazlardır. Zong jiaoxi bu nedenle modern bir üniversitedeki dekana benzemektedir demek mümkündür.

Zong jiaoxi'nin konumunun belirlenmesi, Tongwen Guan'ın gelecekteki gelişimi üzerinde önemli bir etkiye sahip olmuştur. İlk olarak, bu pozisyon, okulun sorunları hakkında daha fazla bilgiye sahip olan fakültenin okul yönetimine katılmasını sağlamıştır. Daha da önemlisi, zong jiaoxi'nin sorumluluğu, Zongli Yamen'in kararlarını etkileyebilecek aşă̆ıdan yukarıya yeni bir kanalın yaratılmasını sağlamıştır. 1869 ile 1900 yılları arasındaki birçok yeni okul politikası, zong jiaoxi'nin önerileriyle ortaya çlkmıştır. Personelin okul işleri üzerindeki etkisinin arttırılması, sonunda Tongwen Guan'ı modern bir okula dönüştüren bir dizi reformu kolaylaştırmıştır.

$8 \quad$ Qing Hanedanı dönemindeki kanun ve yönetmelik derlemeleridir. 


\section{Zong Jiaoxi ve Tongwen Guan'in kabul reformu}

Zongli Yamen 1867 başarısızlı̆̆ından sonra Tongwen Guan'ın rutin işlerine müdahalesini azaltmasına rağmen, yine de okul öğrenci alımlarını kontrol etmiştir. Buna göre öğrenciler dört yöntemle işe alınmıştır. Bunlardan ilki ve en önemlisi, tüm Mançu hanelerinin düzenlendiği Sekiz Sancak'tan tavsiye edilen öğrencilerin kabul edilmesidir. Mançu öğrencileri bürokrasiye katılmak için birden fazla yol arasında seçim yapabildiklerinden, birçoğu Tongwen Guan'ı hor görmüş ve ona kaydolmaya istekli olmamıştır. Bu durumda okul, Qi Rushan'ın belirttiği gibi, 1895'e kadar gelecek vaat eden Mançu öğrencilerini işe alma konusunda başarısız olmaya devam etmiştir (1998: 28). İkinci yöntem, Shanghai ve Guangdong'daki iki yabancı dil okulundan biri tarafından önerilen öğrencilerin kabul edilmesidir (Bao, 1971: 35-36). Ancak bahsi geçen iki okul büyük ölçüde Tongwen Guan'a göre modellendiğinden, öğrencilerinin kalitesi zaten oradaki öğrencilerden daha yüksek değildir. Üçüncü yöntem, 1870'de aydınları kabul etmek için kullanılan yazılı giriş sınavıdır, ancak okulun yeni kabul politikasına karşı düşmanlıkları nedeniyle çok az yetenekli öğrenci bu yöntemle alınmıştır. Daha da kötüsü, Zongli Yamen, başvuru sahiplerini sivil sınavda politika sorularıla test ettiğinden, öğrencilerin yabancı dil, bilim ve teknoloji eğitimi alma potansiyelleri değerlendirilememiştir. Dördüncü yöntem, Zongli Yamen'deki yetkililerin tavsiyesi üzerine alım olmuştur. Danışmanlar genellikle tavsiye ettikleri kişiler hakkında çok az bilgiye sahip olduklarından, bu kabul yöntemi de kabul edilen öğrencilerin kalitesini garanti edememiştir.

Bu yöntemlerle kabul edilen öğrencilerin kalitesizliği, Tongwen Guan'da okumaya başladıktan kısa bir süre sonra ortaya çımıştır. 1884'te Büyük Konsey, Tongwen Guan öğrencileri için Rusça bir dil sınavı düzenlemiştir. Yedi adaydan sadece biri tüm Rus alfabesini tanıyabilmiştir (Qi, 1998: 35). Öğrencilerin kalitesini artırmak için, Ekim 1885'te yeni yönetici Martin, 15 yaşın altındaki Mançu öğrenci uygunluğunu, 15 ila 25 yaş arasındaki Mançu ve Han Çinlilerine genişleterek kabul politikasında reform yapmayı önermiştir. Ayrıca İmparatorluk Akademisi'nden öğrenci alma planına ve eyalet sınavını geçen okur-yazarlara geri dönmeyi önermiştir (Zhongguo shixuehui, 1961: 63-64). Martin reformunun altında yatan mantık, 1866 reformununkiyle aynıdır. Yani Martin, Klasik Çincesi henüz akıcı olmayanlar için, yabancı diller, fen bilimleri ve sosyal bilim konularını aynı anda çalışmanın zor olduğuna inanmıştır. 1884'te Yixin'in yerine Zongli Yamen'in başına geçen Yikuang (奕劻 /1838-1917), Martin'in önerisini kabul etmiş ve Kasım 1885'te yeni kabul politikası kapsamında öğrencilerin alımı başlamıştır.

1866'dakiyle neredeyse aynı olan 1885'teki kabul reformunun muhafazakâr aydınlardan herhangi bir muhalefetle karşılaşmaması dikkat çekici olmuştur. Bu durum kısmen Qing'in 1885'teki Çin-Fransız Savaşı'ndaki yenilgisinden kaynaklanmıştır ve bu da Batı silahlarının üstünlüğünü bir kez daha göstermiştir. Ancak daha önemli bir faktör, aydınların Tongwen Guan tehdidine ilişkin değişen algısında yatmaktadır. Sırasıyla 1867 ve 1887 'de Çin'in elçiliklerinde yalnızca on altı ve on dokuz Tongwen Guan öğrencisi çalışmıştır (Su, 1985: 74). Qing hükümetinin diğer bölümlerinde çalışanlar, pozisyonlarını sivil sınavlarla kazanmışlardır (Zhu, 1983: 63). Tongwen Guan öğrencilerinin kasvetli kariyer beklentileri, esas olarak Zongli Yamen'in Qing bürokrasisindeki yapısal kusurlarından kaynaklanmıştır. Zongli Yamen, üst düzey yönetici yetkililerinin çoğu burada yalnızca ikincil görevlerde bulunduğundan burası geçici bir kuruma benzetilmiştir. Ayrıca, ilk yıllarında tercümanlık memurları gibi gerekli kalıcı pozisyonlar oluşturulamamıştır. Tongwen Guan öğrencileri Zongli Yamen'de memur olarak değil, sadece okul personeli olarak çalışmışlardır. Ayrıca, bürokratik hiyerarşi açısından Zongli Yamen, Büyük Şura'ya bağlı ve Güney ve Kuzey Ticaret Müfettişleri ve illerdeki genel valilerle aynı seviyededir, bu nedenle yabancllar üzerinde yüksek yetkiye sahip olmamıştır (Rudolp, 2008: 105-106). Zongli Yamen'in yetersiz otoritesi, Tongwen Guan öğrencilerinin hükümet görevlerine başarılı bir şekilde 
yerleştirilmesini zorlaştırmıştır. $\mathrm{Bu}$ sorun, Yikuang'ın Zongli Yamen'de tercümanlık memuru pozisyonunu kurmak için onay aldığı 1888 yllına kadar devam etmiştir (Zhu, 1983: 49). Tongwen Guan öğrencilerinin yerleştirme kayıtları, okuryazarları okulun kariyerleri için bir tehdit oluşturmadığına ikna etmiştir, bu nedenle 1885 'te okulun kabul reformuyla ilgilenmemişlerdir.

Muhafazakâr aydınların Tongwen Guan'a karşı düşmanlığındaki düşüş, 1886'da öğrenci toplamadaki başarısına katkıda bulunmuştur. Sınava girenlerin sayısı dört kattan fazla artmış (1876'da 76'dan 394'e) ve 108 öğrenci kabul edilmiştir (Zhongguo shixuehui, 1961: 65-66). Bu kabul reformu öğrencilerin kalitesini artırmaya yardımcı olmuştur. Qi Rushan 1894'te Tongwen Guan'a kaydolduğunda, okulda on yll öncesine göre daha çalışkan öğrencilerin olduğunu belirtmiştir (1998: 40).

Ne yazık ki, kabul reformunun olumlu etkisi, yine de, Tongwen Guan'ın yetersiz yönetimi tarafından kısıtlanmıştır. Göze çarpan bir sorun ise rutin denetleme sınavlarında kopya çekilmesi olmuştur. Zongli Yamen, bazı öğrencilerin sınava girmeleri için başkalarını tuttuğunu veya hazırlanan notları kullanarak kopya çektiklerini öğrenmiştir. Bu nedenle, Aralık 1876'da sınav kurallarını sıkılaştırmak için bir yönerge yayınlanmıştır (Zhu, 1983: 126). Daha ciddi bir sorun ise sınavlara düşük katılım olmasıdır. Birçok öğrenci hastalık, evlilik, yas ve devlet kurumlarında çalışmak gibi çeşitli nedenlerle düzenli olarak okula gidememiştir. En düşük katılım oranlarından biri, 1894'ün başlarında, ortalama on öğrenciden sadece bir veya ikisinin sınava katıldığı zaman ortaya çımıştır (Zhu, 1983: 137). Zongli Yamen, dokuz yıl içinde okulun devam oranını artırmasını zorunlu kılan on bir yönerge yayınlamıştır (Zhu, 1983: 127138).

Tongwen Guan'daki öğrenci disiplini konusu, kısmen 1886'dan önce kabul edilen öğrencilerin yetersiz seviyelerinden kaynaklanmıştır. Ancak, daha önemli bir neden idari personel eksikliği olmuştur. Hem Çinli hem de yabancı eğitmenler yalnızca öğretimden sorumlu olmuş ve yönetimde hiçbir rol oynamamışlardır. Bazı seçkin öğrenciler yardımcı eğitmenler olarak çalışmıslardır, ancak rolleri idari asistanlardan çok öğretim asistanlarına benzetilebilmektedir. Bu, tüm akademik ve idari işlerin zong jiaoxi ve müfettiş yardımcılarının üzerine düştüğü anlamına gelmektedir. Ondan fazla eğitmen, yüzden fazla öğrenciyle ilgili işlerden hiçbir idari yardım almadan sorumlu olmuşlardır. Öğrenci disiplini sorununu alevlendiren idari personelin eksikliği, kabul reformunun olası başarılarını büyük ölçüde engellemiştir.

\section{Birinci Çin-Japon savaşı ve Tongwen Guan krizi}

Çin'in 1895'teki Birinci Çin-Japon Savaşı'ndaki yenilgisi, Tongwen Guan'ın kaderini temelden şekillendirmiştir. Son araştırmalar, savaşın sonucunun Çin ve Japonya arasındaki teknolojik uçurumdan kaynaklı olduğu yönünde olmuştur. Örneğin, Allen Fung, Japon birliklerinin savaşta Çinli muadillerinden daha donanımlı olmadığını ve Çin'in çöküşünün ana nedeninin daha çok Çinli askerlerin askeri eğitim ve disiplin eksikliği olduğunu savunmuş̧tur (1996). Bu arada Benjamin A. Elman, Çin ordusunda, mermilerin çoğu çimento ile dolu olduğu için ciddi bir yolsuzluk olduğuna da dikkat çekmiştir (2004: 330). Savaştaki zafer birden fazla faktör tarafından belirlense de, Qing'in sonlarında kamuoyu, Çin'in geri teknolojisindeki askeri yenilgileri suçlama eğiliminde olmuştur.

Qing'in askeri başarısızlı̆̆ının anlatısı, Kendini Güçlendirme Hareketine inananlara yönelik sert eleştirilere yol açmıştır. Japonya'nın başarısının bakış açısından pek çok okuryazar, Kendini Güçlendirme Hareketi'ni, Batı teknolojisini modası geçmiş bir çerçeveye dayatmak için başarısız bir girişim olarak algılamıştır. Hareket doktrinini reddetmeleri, cephanelikler, donanma, fabrikalar ve 
akademiler gibi yeni kurumların Batı tarzı işletmeler değil, daha çok geri Çin kurumları olduğu anlatısını üretmiştir. Bu aydınlar, Çin'i güçlendirmek için "eski” yapılarda reform yapmak ve yeni kurumlar kurmak istemişlerdir. Bu arada, bazı okuryazarlar, bilim ve teknolojinin Batı gücünün ana kaynağı olduğu varsayımını da yeniden gözden geçirmişlerdir. Japonya'nın yükselişini, yalnızca Batı bilimini benimsemesinden ziyade Meiji Restorasyonundan sonra inşa edilen Batılılaşmış sosyopolitik yapısının bir sonucu olarak görmüşlerdir. Bu nedenle Qing hanedanını güçlendirmek için siyasi, ekonomik, eğitimsel ve askeri alanlarda bir reformu savunmaya başlamışlardır. Bu atmosfer içinde, Tongwen Guan kaçınılmaz olarak sert eleştirilerle karşılaşmıştır.

Reformist aydınlar, Tongwen Guan'ı Çin'i güçlendirmek için personel yetiştiremediği gerekçesiyle eleştirmişlerdir. Okulun müfredatını, eğitim başarısını engelleyen önemli bir faktör olarak görmüşlerdir. Bir sansürcü olan Chen Qizhang, okulu yabancı dile fen eğitiminden daha fazla öncelik vermekle suçlamıştır (Zhu, 1983: 590-591). Li Duanfen (李端荣/ 1833-1907) ve Liang Qichao (梁啟超/ 1873-1929), bu konuyu Batı öğreniminin önemli bir yönü olarak gördükleri için müfredata daha fazla siyaset bilimi ve ekonomi dersi eklenmesi gerektiğini savunmuşlardır (Liang, 1989: 19-20). Üç reformcu, Batı öğreniminin okulda nasıl öğretildiği konusunda da endişeli olmuşlardır. Öğrencilerin çok fazla alanla uğraşırlarsa bir konuda uzmanlaşamayacaklarını savunmuşlar ve bu nedenle sanat bölümü müfredatını uzmanlık ve profesyonelleşmeden yoksun olmakla eleştirmişlerdir (Liang, 1989: 19-20). Reformistlerin Tongwen Guan'daki sanat eğitimine saldırıları, on dokuzuncu yüzyll modernleşmesiyle kariyerlerin artan karmaşıklığına yol açtığından, yükseköğretimde profesyonelleşme ve uzmanlaşmaya yönelik küresel eğilimin bir parçası olmuştur. Bu eleştirmenler, çok yönlü kültürlü geleneksel idealin, Çin'i modernleştirme görevini yerine getiremeyeceğine inanmışlardır, çünkü bunlar Batı öğrenimi alanlarında uzmanlık geliştirememişlerdir. Böylece Martin'in hümanist Konfüçyüs eğitimini Batılı bir bilim eğitimi ile birleştiren liberal sanatlar müfredatı vizyonunu reddetmişler ve bunun yerine uzmanların eğitimini talep etmişlerdir.

Okul müfredatına yönelik sert eleştirilerle karşı karşıya kalan Zongli Yamen, yeniden müfredat reformuna acil bir ihtiyaç olduğunu keşfetmiş̧tir. Tongwen Guan'ı Batı bilim ve teknolojisini incelemek için bir üs haline getirme gündemini geri getirmişlerdir. Okulun gözden geçirilmiş vizyonu, 1895'te Martin'in yerine zong jiaoxi olarak geçen Charles Henry Oliver'ın (1857-1937) vizyonuyla aynı doğrultuda olmuştur. Zongli Yamen ve Oliver'ın okulun gelişimi konusunda fikir birliği, 1895'ten sonra bir dizi reforma yol açmıştır. Bu reformlar, öğrencilerin bilimsel konulara ilgisini artırmaya yönelik tedbirlerle başlamıştır. Ağustos 1895 'te Oliver, öğrencilerin aylık maaşlarını artırmak için bilim çalışmasının bir ön koşul haline getirilmesi fikrini ileri sürmüştür (Zhu, 1983: 139). Önerisi aynı ay içinde Zongli Yamen tarafından onaylanmış ve daha da ileri giderek bilimsel konularda okuyan öğrencilere ekstra ödüller verilmiştir. Oliver daha sonra 1897'de Zongli Yamen tarafından uygulamaya konan daha iddialı bir reform planı hazırlamıştır. Daha yetenekli öğrenciler yetiştirmek için daha düşük rütbeli yetkilileri işe almaya yeniden başlamayı önermiştir (Zhu, 1983: 147-148). Ayrıca okuldaki fen eğitimini çeşitli şekillerde geliştirmeye çalışmıştır. İlk olarak, daha büyük bir fen eğitimi alıcıları oluşturmak adına Klasik Çince öğrenmesi gerekmeyen öğrenciler için bu tür derslerin zorunlu hale getirilmesini savunmuş ve ikinci olarak, fen müfredatını genişletmek için bir Mühendislik ve Haritacıllk Bölümü kurulmasını önermiştir (Zhu, 1983: 147-148).

$\mathrm{Bu}$ reform, reformistlerin Tongwen Guan'daki bilim eğitimine yönelik eleştirilerini ele alsa da, reformistlerin talep ettiği gibi müfredata daha fazla siyaset bilimi veya ekonomi eklememiştir. Bu, büyük ölçüde, Kendi Kendini Güçlendirenlerin Çin'i neyin güçlendirebileceğine ilişkin algılarından kaynaklanmaktadır. Siyaset bilimi ve ekonomide devlet refahının sırrını "keşfeden" reformistlerin 
aksine, Kendini Güçlendirenler Batı bilim ve teknolojisini temel faktör olarak görmüşlerdir. Ancak Batılı beşeri bilimler ve sosyal bilimler üzerine kurslar açmak için çok az motivasyonları olmuştur. Reform, okula profesyonelleşme ve uzmanlaşma da getirmemiştir. Kendi Kendini Güçlendirenler, temel ilkeler için Çin öğrenimi ve pratik uygulama için Batı öğrenimi doktrinini benimserken, Çin'in Konfüçyüs klasikleri üzerine kurulu sosyal, politik ve kültürel yapısını korumakta ısrar etmişlerdir. Böylece müfredatta Çince öğrenmenin rolünü baltalayacak bir uzman eğitim planını reddetmişlerdir. Onlar için "ideal”, geniş bir konu yelpazesi hakkında bilgi sahibi olan çok yönlü öğrenciler olarak kalmıştır. Sonuç olarak, liberal sanatlar müfredatını değiştirmek konusunda isteksiz olmuşlardır.

Zongli Yamen'in sosyal bilimler müfredatını genişletme ve Tongwen Guan'a profesyonellik ve uzmanlık kazandırma konusundaki tereddüdüne rağmen, reform okulun gelişimi için yeni bir fırsat sunmuştur. Aydınların Batı bilim ve teknolojisini inceleme arzusunun artmasının ardından, reform daha fazla sayıda öğrenci çekmeyi başarmıştır. 1895'ten sonra, Tongwen Guan başvuru sayısında eşi görülmemiş bir artışla karş̧laşmış ve kayıtlı öğrenci sayısı 1896'da 119'a ulaşmıştır. Oliver, okulda izin verilen maksimum öğrenci sayısı 120 olduğu için öğrenci alımını geçici olarak durdurmayı bile önermiştir (Zhu, 1983: 145). Başvuru sayısındaki artış, kabul için rekabeti de kızıştırmıştır. Okul, öğrencileri değerlendirmenin ana yöntemi olarak giriş sınavını uygulamaya başlamış ve bu da gelecek vaat eden adayların seçilmesine yardımcı olmuştur (Qi, 1998: 37).

Reform önemli bir başarı elde edemeden önce, okul 190o'den sonra Boxer İsyanı (1899-1901) nedeniyle iki yıllığına kapatılmıştır. Okulda ani ve niteliksel bir gelişme göremeyen aydınlar, okula olan güvenlerini yitirmiş ve sahip olduğu potansiyeli görmezden gelmişlerdir. Bu eğitim "başarısızlığının" nedenlerini araştıranlardan bazıları okulun yapısını suçlamışlardır. İlk guanxue dachen (管學大臣/ eğitim komiseri) olan Sun Jianai (孙家任/ 1827-1909), Kendini Güçlendirme Hareketi sırasında kurulan tüm askeri akademilerle birlikte Tongwen Guan'ı eski tarz kurumlar olarak sinıflandırmıştır (Zhu, 1983: 623). Sun'ın gözünde, ilk yıllarında cesur müfredatı ve kabul politikaları nedeniyle eleştirilen Tongwen Guan, muhafazakâr bir okul haline gelmiştir. O ve siyasi reform özlemi çeken diğerleri, 1898'de Pekin İmparatorluk Üniversitesi şeklinde ortaya çıkan modern bir üniversitenin planını çizmişlerdir (Zhu, 1983: 485). Müfredatına hem Çin hem de Batı dillerini ve öğrenimi entegre eden Pekin İmparatorluk Üniversitesi, giderek pahalı ama işlevsiz bir kurum gibi görünen Tongwen Guan'ı gölgede bırakmıştır. 1898 gibi erken bir tarihte, bazı aydınlar Tongwen Guan'ın tamamen kaldırılmasını veya diğer okullarla birleştirilmesini önermişlerdir ( $\mathrm{Su}, 1985$ : 87). Sonunda, Qing hükümeti onu 1902'de Pekin İmparatorluk Üniversitesi'ne dâhil etmeye karar vermiştir.

\section{Sonuç}

Tongwen Guan sadece kırk ylllık varlığına rağmen, onun çalışmaları Çin'in moderniteye giden yolunun daha iyi anlaşılmasını kolaylaştırmaya hizmet etmektedir. Okulun karşılaştığı 1867 başarısızlığı, Çin ile Batı arasındaki ideolojik farklılığın Çin'in 1895 'ten önce Batı bilim ve teknolojisini benimseme konusundaki isteksizliğine yol açtığını ileri süren John King Fairbank ve Ssu-yu Teng (1954), Albert Feuerwerker (1958) ve Mary Clabaugh Wright'ın (1962) modern Çin tarihi araştırmalarındaki geleneksel görüşlerini yeniden incelememize yardımcı olmaktadır. Kuşkusuz, on dokuzuncu yüzyılın sonlarında Çin'de yabancı düşmanı bir duygu oluşmuştur. Sadece muhafazakâr okuryazarlar değil, aynı zamanda Kendini Güçlendirenler de Batıllılara çok az güvenmişlerdir, bu doğrultuda Tongwen Guan öğrencileri Batı bilimi ve teknolojisi hakkında bilgi edindikten sonra yabancı eğitmenleri Tongwen Guan öğrencileriyle değiştirmek istemişlerdir. Aynı zamanda, Qing okuryazarlarının Batı bilim ve teknolojisini hor görmeleri de göze çarpmaktadır. Çin'in kültürel üstünlü̆̆̈̈ne ilişkin algıları, 
muhafazakârların Batı öğreniminin önemini reddetmesinde ve Kendini Güçlendirenlerin Batı öğreniminin Çin öğrenimini tamamlayıcı olduğu fikrinde bulunabilmektedir. Buna rağmen, Tongwen Guan'ın tarihi, okulun gelişimini engelleyen en önemli faktörlerin yabancı düşmanlı̆̆ ve bilimi küçümseme olmadığını ortaya koymaktadır. Aydınlar ne 1866 reformundan önce ne de okulun kariyerlerini tehdit etmediğini fark ettikten sonra okula düşmanlığı bırakmışlardır. Ancak okulun aydınları astronomi ve matematik okumak üzere işe alma planının içerdiği tehlikelerden endişe duyduklarında buna karşı çıkmışlardır. Yabancı düşmanlığı ve Çin'in kültürel üstünlüğü söylemi, büyük ölçüde muhafazakâr aydınların çıkarlarını yükselen güçlerin çıkarlarına karşı koruma aracı olarak kullanılmıştır. Tongwen Guan reformu, böylece, Çin'in moderniteye doğru yürüyüşündeki gerilemeleri anlamada "yeni" ve "eski"nin "Çin'e karşı Batı"dan daha yararlı kategoriler olduğunu öne sürmüştür.

Ayrıca, Tongwen Guan'ın örgütsel değişiklikleri, Batı bilim ve teknolojisini eski kültüre uyarlamaya güvenme girişimi nedeniyle Kendini Güçlendirme Hareketi'nin başarısız olduğu varsayımını yeniden gözden geçirmemize yardımcı olmaktadır. Bu yaklaşım, kurumsal dinamikleri görmezden gelmekte ve Kendini Güçlendirme Hareketi'nin bir parçası olarak inşa edilen yeni kurumları, onları yeni şişelerde eski şarap olarak tasvir ederek küçümsemektedir. Tongwen Guan'ın tarihi, okulun idari personelinin çabalarıyla daha sonra Amerika'daki bir liberal sanat kolejine eşdeğer bir kuruma dönüştürülen eski tarz bir yabancı dil okulu olarak başladığını göstermektedir. Bu tür bir organizasyonel yenilik, Kendini Güçlendirme Hareketinde nadir görülen bir şey değildir.

Son olarak, Tongwen Guan'ı kurumsalcı bir bakış açısıyla araştırmak, sözde "başarısız" Kendi Kendini Güçlendirme Hareketi'nin daha iyi anlaşılmasını kolaylaştırmaktadır. Zongli Yamen ve zong jiaoxi arasındaki etkileşime daha yakından bakmak, okuldaki kurumsal kısıtlamaları ve yönetimsel eksiklikleri ortaya çlkarmaktadır. İki taraf 1895 yılına kadar okulla ilgili aynı vizyonu paylaşmadıkları için faaliyetlerini koordine edememişlerdir. Okul, mesleki eğitim vermekle liberal sanatlar eğitimi vermek arasında kalmıştır. Zongli Yamen'in öğrenci alımı ve sınavları üzerindeki kontrolü, okulun müfredatının ve kabul reformlarının etkilerini sınırlamıştır. İki taraf nihayet 1895 yılında okulun gelişimi konusunda fikir birliğine vardığında, hızla değişen yerel ve uluslararası ortamlar, onlara aydınların beklentilerini yerine getirmek için yeterli zaman tanımamıştır. Bu tür kurumsal zayıflık sadece Tongwen Guan'a özgü değildir, Kendini Güçlendirenler tarafindan kurulan birçok kurumda yaygındır. Örneğin, Foochow Deniz Koleji'nin başarıları, geleneksel bütçeleme ve muhasebe yöntemlerinin sınırlamalarının yanı sıra yönetim personeli arasındaki teknolojik bilgi eksikliği nedeniyle büyük ölçüde baltalanmış ve bunların tümü sonunda maliyet aşımlarına yol açmıştır. Jiangnan Arsenal reformunun gösterdiği gibi, devlete ait işletmelerdeki bu tür sorunlar Birinci Çin-Japon Savaşı'ndan sonra da devam etmiştir. Qing hükümetinin, Liangjiang (两江) Valisi Zhang Zhidong'un (張之洞/ 1837-1909) Jiangnan'daki etkisini kontrol etme gündemi, 1895 ve 1911 ylları arasında cephanelik organizasyonunun reformunu engellemiştir. Başka bir deyişle, kurumsal özerkliğin olmaması, devlete ait işletmeleri hükümet içindeki siyasi mücadelelere karşı savunmasız hale getirmiştir. Bu açıdan bakıldığında, Çin/Batı ve Bilim/Klasik ikilemleriyle karşılaştırıldığında, kurumsal kısıtlamalar, Kendini Güçlendirenler'in çeşitli çabalarının aşil topuğu olmuş ve bazen onlara ölümcül darbeyi vurmuştur. 


\section{Kaynakça}

A, Y. 阿英 (1955). 晚清小说史 (Wan Qing xiao shuo shi). Pekin: Zuojia Chubanshe.

A, Y. 阿英 (1957). 晚清戏曲小说目录 (Wan Qing xi qu xiao shuo mu lu). Shanghai: Shanghai Gudian Wenxue Chubanshe.

Bao, Y. 寶垟, ed. (1971). 籌辦夷務始末: 同治朝 (Chouban yiwu shimo: Tongzhi chao 籌辦夷務始末: 同 治朝). vol. 8. Taipei: Wenhai Chubanshe.

Biggerstaff, K. (1961). The Earliest Modern Government Schools in China. Ithaca: Cornell University Press.

Chen, X. 陳向陽. (2004). 晚清京師同文館研究 (Wanqing jingshi Tongwen Guan yanjiu). Guangzhou: Guangdong Gaodeng Jiaoyu Chubanshe.

Clyde, P. \& Beers, B. (1966). The Far East. Englewood Cliffs: New Jersey. Prentice Hall.

Cordier, H. (1901). L'Imprimerie Sino-Europeenne an Chine. Bibliographie des ouvrages publies en Chine par les Europeens au XVIIe et XVIIIe siecle. Paris.

Ding, Z. 丁偉志 \& Chen, S. 陳松. (1995). 中體西用之間 (Zhongti xiyong zhijian). Beijing: Zhongguo Shehui Kexue Chubanshe.

Elman, A. B. (1990). From Philosophy to Philology: Intellectual and Social Aspects of Change in Late Imperial China. Cambridge: Council on East Asian Studies, Harvard University Press.

Elman, A. B. (2004). "Naval Warfare and the Refraction of China's Self-Strengthening Reforms into Scientific and Technological Failure, 1865-1895." Modern Asian Studies. 38(2): 283-326.

Elman, A. B. (2005). On Their Own Terms: Science and China, 1550-190o. Cambridge: Harvard University Press.

Feng, G. 馮桂芬 (1885). 校分盧抗議 (Chiao-pin-lu k'ang-i). Vol.2. Papers Relating to Foreign Affairs. (1867/ 1868). Washington D. C.

Feng, G. 馮桂芬. (1967). 采西學議 (Cai xixue yi). içinde “校邠盧 議 (Jiaobinlu kangyi)”. Feng Guifen 馮 桂芬 (Eds.). Taipei: Xuehai Chubaishe.

Fung, A. (1996). “Testing the Self-Strengthening: The Chinese Army in the Sino-Japanese War of 18941895." Modern Asian Studies 30: 1007-031.

Hu，D. 胡代聰. (1997). “中國第一所外語外事學校同文館：兼論圍繞它的文化，政治衝突(Zhongguo diyisuo waiyu waishi xuexiao tongwenguan: Jianlun weirao tade wenhua, zhengzhi chongtu).”外 交學院學報 (Waïiao xueyuan xuebao). 4: 42-49.

IWSM. (1929-31). Ch'ou- pan i-wu shih-mo. Pekin: Palace Museum. Vol.250.

Jia，Y. 賈永堂. (2001). “我國現代改革中教育觀轉變難的文化原因探析 (Woguo xiandai gaige zhong jiaoyuguan zhuanbiannan de wenhua yuanyin tanxi)." 現代大學研究 (Xiandai daxue yanjiu). 2: 33-36.

Jia, Z. 賈禎. (1970). 籌辦夷務始末: 略㱆朝 (Chouban yiwu shimo: Xianfeng chao). Vol. 71. Taipei: Wenhai Chubanshe.

Liang, Q. 梁啟超. (1989). 飲冰室合集(Yibinshi heji). Beijing: Zhonghua Shuju. 
Li, X. 李欣然. (2015). “爭於廟堂的道器與中西一同治五、六 年間的天文算學館之爭 (Zhengyu miaotang de daoqi yu zhongxi一Tongzhi wuliunian jian de tianwen suanxue guan zhi zheng)." 社會科學研 究 (Shehui kexue yanjiu). 4: 182-187.

Lü, J. 呂景琳. \& Zhang, D. 張德信. (1988). “略論京師同文館與人才培養 (Lüelun jingshi Tongwen Guan yu rencai peiyang).”近代史研究 (Jindaishi yanjiu). 47(5): 86-101.

Ma, Z. 马祖毅 (1984). 中国翻译简史：五四以前部分 (Zhongguo fan yi jian shi: “Wu si” yi qian bu fen). Pekin: Zhongguo Dai wai Fanyi Chuban Gongsi.

Nanqiu, L. 黎难秋 (2006). 中国科学翻译史 (Zhongguo Kexue Fanyi Shi). Anhui: Zhongguo Kexue Jishu Daxue Chubanshe.

O’Brien, M. J. (1870). “The Peking College.” North China Herald. January 25.

Papers Relating to Foreign Affairs. (1867/ 1868). I. s.473-474.

Peake, C. (1932). Nationalism and Education in Modern China. New York: Columbia University Press.

Qi, R. 齊如山. (1998). 齊如山回憶錄(Qi Rushan huiyi lu). Beijing: Zhongguo Xiju Chubanshe.

Ruan, Y. 阮元 (1980). 十三經注疏 (Shi San Jing Zhu Shu). Pekin: Zhonghua Shu Ju. Vol. 2.

Rudolph, J. (2008). Negotiated Power in Late Imperial China: The Zongli Yamen and the Politics of Reform. Ithaca: Cornell University East Asia Program.

Su, J. 蘇精. (1985). 清末同文館及其師生 (Qingji tongwen guan jiqi shisheng). Taipei: Su jing.

Wang, J. 汪敬虞. (1987). 赫德與近代中西關係(Hede yu jindai zhongxi guanxi). Beijing: Beijing Renmin Chubanshe.

Zhongguo shixuehui 中國近代史學會. ed. (1961). 中國近代史資料彙編: 洋務運動 (Zhongguo jindaishi ziliao huibian: Yangwu yundong). Shanghai: Shanghai Renmin Chubanshe.

Zhu, Y. 朱有瓛. ed. (1983). 中國近代學制史料 (Zhongguo jindai xuezhi shiliao). Shanghai: East China Normal University Press.

Xiong, Y. 熊月之 (1994). 西学东渐与晚清社会 (Xi xue dong jian yu wan Qing she hui). Shanghai: Shanghai Renmin Chubanshe. 